The Impact of Global Warming on Texas 
THIS PAGE INTENTIONALLY LEFT BLANK 


\section{The Impact of Global Warming on Texas}

\section{Second edition}

Edited by Jurgen Schmandt, Gerald R. North, and Judith Clarkson 
Support for this book comes from an endowment for environmental studies made possible by generous contributions from Richard C. Bartlett, Susan Aspinall Block, and the National Endowment for the Humanities.

Copyright (C) 20I I by the University of Texas Press

All rights reserved

Printed in the United States of America

Second edition, 20I I

Requests for permission to reproduce material from this work should be sent to:

Permissions

University of Texas Press

P.O. Box 7819

Austin, TX 78713-7819

www.utexas.edu/utpress/about/bpermission.html

( The paper used in this book meets the minimum requirements of ANSI/NISO Z39.48-I992 (RI997) (Permanence of Paper).

Library of Congress Cataloging-in-Publication Data

The impact of global warming on Texas / edited by Jurgen Schmandt, Gerald R. North, and Judith Clarkson. - 2nd ed.

p. $\mathrm{cm}$.

Includes bibliographical references and index.

ISBN 978-0-292-72330-6 (cl. : alk. paper)

1. Global warming-Texas. 2. Climatic changes-Environmental aspects-

Texas. I. Schmandt, Jurgen. II. Clarkson, Judith. III. North, Gerald R.

QC98I.8.G56I47 20I I

$363.738^{\prime} 74209764-\mathrm{dc2} 2$

20II0066I4

ISBN 978-0-292-73324-4 (E-book) 